\title{
Application of dehydration technologies as a tool to foster bioeconomics and fruit consumption in rural populations in South America
}

\author{
Vinícius Soares de OLIVEIRA ${ }^{1 *}$ (D), Juliana Rodrigues DONADON ${ }^{1}$, Rita de Cássia Avellaneda GUIMARÃES ${ }^{1}$, \\ Priscila Aiko HIANE ${ }^{1}$
}

\begin{abstract}
Strengthening the use and improvement of species native to South America may lead to the development of new food products with high nutritional potential, in addition to contributing to disease prevention, thus meeting the varied demands of consumption. The focus of this strategy is especially on native plant species and/or introduced species, but which have become very popular for presenting edible fruits appreciated for their characteristic flavor and aroma. In addition, the pulp of such fruits has antioxidant potential, which makes it possible to call them functional foods. However, perishability and seasonality hinder production on a larger scale, and it is necessary to explore conservation alternatives to make the fruit pulp available all year round. Studies have shown the use of conventional technologies and emerging and promising technologies for the preservation of the organoleptic characteristics of fruits. Finally, the strengths and weaknesses of each conservation technique are discussed in view of the variety of fruits found in different regions of the world and especially in South American countries.
\end{abstract}

Keywords: food technology; dehydration; sustainability; antioxidants.

Practical Application: Establish technical and scientific bases to disseminate technologies for dehydration of native fruits.

\section{Introduction}

South America has the largest biodiversity in the world. It is a world heritage of plant genetic resources that plays a strategic role in sustainable development and increased quality of life, especially for vulnerable populations (Boeri et al., 2020; Abreu et al., 2017). The perishability and seasonality of native fruits are attenuating factors for the food fragility of traditional populations, in addition to economically hindering production on a larger scale, the development of the bioeconomy, and the creation of agro-industries and rural associations (Sasson \& Malpica, 2018).

Despite the richness of forage, apiculture, fruit, and timber species in Latin American countries, native peoples, such as diverse indigenous ethnic groups, traditional communities, riverside communities, quilombolas, "caipiras," and wetland inhabitants, face subsistence difficulties mainly due to the lack of food security (van Noordwijk et al., 2020).

Fruit consumption is inversely proportional to the risk of chronic non-communicable diseases, especially cardiovascular and neoplastic diseases (Scoditti et al., 2019). In general, fruits are a source of potassium, dietary fiber, folate, antioxidants, and other bioactive phytochemicals. However, the consumption of fruits and vegetables is also inversely proportional to per capita household income (Benton \& Young, 2019). The minimum recommended food consumption is $400 \mathrm{~g} /$ day, which corresponds in Brazil to 6-7\% of the total daily calories of a diet of $2,300 \mathrm{kcal}$ (Herforth et al., 2020).

Therefore, it is necessary to look for alternatives that allow the integration of biodiversity and traditional and scientifictechnological knowledge by applying conservation techniques that make traditional fruit pulps available all year round (Sanchez et al., 2020).

Over time and with the growing demand for food, preservation techniques have been improved and modernized. Irradiation, high-pressure food preservation, the pulsed electric field effect, cooling, freezing, fermentation, and drying have been developed to preserve food and maintain its nutritional value and texture. Different chemical reagents have also been introduced as food additives and preservatives. However, there is a growing concern with the use of chemical additives and preservatives in foods due to possible health risks (Amit et al., 2017).

Among the various food preservation techniques available dehydration has numerous advantages. It reduces the weight and volume of food, facilitates storage, conditioning, and transport, in addition to providing different flavors and smells. With all these benefits, drying is apparently the cheapest method of preserving food (Ray et al., 2016).

Different techniques, such as natural convective drying, sun drying, forced convective drying, microwave drying, foam 
mat drying, lyophilization, and atomization (spray drying) can be used to dry fruits and vegetables. In addition to promoting dehydration, some of these methods allow the microencapsulation of food and food products (Ozkan et al., 2019), providing better conditions of protection, stability, solubility, and controlled release of food and its bioactive compounds (Ray et al., 2016).

Another important alternative for the dehydration of fruits and vegetables is osmotic dehydration followed by convective drying. It is widely used as a simple and effective method when applied to treat small quantities at the laboratory and/or manually. However, it is little explored in agro-industries and rural properties due to the difficulty of large-scale production (Rodríguez et al., 2018).

The foam mat drying method was developed seeking to decrease drying time and temperature of foods normally dehydrated by the traditional drying method. It uses a forced air circulation oven due to the greater exposed surface area, thus decreasing energy consumption (Abbasi \& Azizpour, 2016). Lyophilization is a drying process consisting of three main stages: product freezing, primary drying, and secondary drying. It has been used to obtain dehydrated products with a superior quality and is recommended for heat-sensitive and oxidation-prone products (Kawasaki et al., 2019).

Spray drying is a well-established and widely used technique for turning liquid food into powder. The initial food must be liquid. It can be a solution, an emulsion, or a suspension. Heat-resistant and heat-sensitive products can be spray dried (Assadpour \& Jafari, 2019).The purpose of this review is to seek information on drying methods that may be used in the processing of pulps and other products made of traditional South American fruits.

\section{Materials and methods}

This study is a literature review and was conducted from May to December 2020. The following databases were used as data sources: Latin American and Caribbean Literature on Health Sciences (LILACS), Scientific Electronic Library Online (SCIELO), International Literature on Health Sciences (MEDLINE), CAPES Journals Portal, and Google Scholar. Studies published between 2001 and 2020 were selected. A combined search was made using search keywords food technology, dehydration, sustainability, and natural antioxidants. For the combined search, the Boolean operator AND was used/applied to facilitate the search and selection process. For a better discussion of publications and materials collected in this study, the present research was organized into five thematic units that describe the main dehydration techniques used for drying native and exotic fruits consumed by populations in South America.

\section{Results and discussion}

Dehydration is an easy-to-apply process that considerably reduces product moisture and consequently water activity, minimizing physical, chemical, biochemical, and microbiological changes during storage, in addition to reducing packaging and transportation costs. However, during the dehydration process, some constituents such as vitamin C, anthocyanins, and carotenoids may degrade mainly due to heat, sudden temperature changes, contact with oxygen, and process time. Therefore, several dehydration techniques are continuously studied aiming the retention of these nutritional constituents (Ban et al., 2020). Table 1 show the main dehydration techniques used for drying fruits.

\subsection{Dehydration by foam mat}

This technology implies the incorporation of foaming agents into the sample to be dehydrated. After an intense homogenization, a thin layer of foam is added to a drying tray that is subjected to the dehydration process at different temperatures ranging from 50 to $80^{\circ} \mathrm{C}$. At the end, the result is a powder product with a good color, flavor, and bioactives retention (Sun et al., 2020).

Foam mat dehydration can be applied in the production of food products with a high added value, such as smoothie of banana and strawberry. Strawberries are a very popular fruit worldwide in natura and also in beverages. Banana is the fruit of preference in South America, widely available on the market throughout the year, which contributes strongly to its high consumption. Aiming a product with a healthy appeal that attracts consumers, strawberry pulp and banana powder were produced using the foam mat method. The result was a smoothie with low added sugar and the potential to be consumed by niche markets due to its characteristic similar as those of natural fruit drinks (Guazi et al., 2019).

In order to obtain pequi (Caryocar brasiliense Camb.) powder, rich in carotenoids, the foam layer dehydration method was applied, obtaining at the end of the process a pequi pulp powder (Pinto et al., 2018). Another study reported vitamin C retention in guavira pulp (Campomanesia adamantium Cambess O. Berg) dehydrated using the foam mat method, obtaining powdered guavira pulp with $98 \mathrm{mg}$ of vitamin C in $100 \mathrm{~g}$ of powder after 45 days of storage (Breda et al., 2012).

The difficulties the authors reported in relation to the method are relevant to the problem of developing this technique on a large scale, as large trays with huge drying ovens would be necessary. Even so, we can verify that foam mat drying is a promising technology for the dehydration of fruits with maintenance of the organoleptic characteristics and antioxidant properties, even though it is a technique of simple execution and low cost, which makes it possible to offer products at an affordable price to consumers.

\subsection{Osmotic dehydration and convective dehydration in trays}

The osmotic dehydration technique involves the migration of intracellular water to the extracellular medium through the osmotic gradient. Typically, the food to be dehydrated is immersed in an isotonic solution composed of sucrose and then convective drying is applied in trays, however with lower temperatures and drying times compared to the convective technique in trays (Ahmed et al., 2016).

Oven dehydration with an airflow, or also classified as hot air convective drying, is the most common method applied for drying vegetables. The process consists of removing water from 
Table 1. Successful experiences in the dehydration of fruits popularly consumed in South America.

\begin{tabular}{|c|c|c|c|}
\hline Drying Process & Species & Benefits & Reference \\
\hline \multirow[t]{5}{*}{$\begin{array}{l}\text { Drying } \\
\text { convective oven combined } \\
\text { with other technologies }\end{array}$} & $\begin{array}{l}\text { Pear } \\
\text { Pyrus communis }\end{array}$ & $\begin{array}{l}\text { The combination of osmotic dehydration with conventional } \\
\text { dehydration resulted in a } 17 \% \text { higher overall acceptability and reduced } \\
\text { the dehydration time by } 42 \% \text {. }\end{array}$ & $\begin{array}{l}\text { Costa Ribeiro et al. } \\
(2016)\end{array}$ \\
\hline & $\begin{array}{l}\text { Kiwi } \\
\text { Actinidia chinensis }\end{array}$ & $\begin{array}{l}\text { Pre-treatment with ultrasound positively affected the chlorophyll } \\
\text { content, while the combination of convection with ultrasound } \\
\text { improved the general characteristics of the fruit. }\end{array}$ & Nowacka et al. (2017) \\
\hline & $\begin{array}{l}\text { Strawberry Fragaria } \\
\text { ananassa }\end{array}$ & $\begin{array}{l}\text { The drying time of strawberries reduced by } 28 \% \text { when the samples } \\
\text { were previously treated with ultrasound in a sucrose solution before } \\
\text { conventional drying. }\end{array}$ & Amami et al. (2017) \\
\hline & $\begin{array}{l}\text { Persimmon } \\
\text { Diospyrus kaki }\end{array}$ & $\begin{array}{l}\text { Osmotic dehydration combined with ultrasound before drying by } \\
\text { convection decreased the total drying time without changing the color } \\
\text { of persimmons. }\end{array}$ & Bozkir et al. (2019) \\
\hline & $\begin{array}{l}\text { Cagaita } \\
\text { Eugenia dysenterica }\end{array}$ & $\begin{array}{l}\text { The sensory analysis showed that the dehydrated cagaita, combining } \\
\text { osmotic and convective dehydration, was well accepted, constituting a } \\
\text { valid option for adding value to the fruit. }\end{array}$ & Silva et al. (2015) \\
\hline \multirow[t]{5}{*}{$\begin{array}{l}\text { Foam mat } \\
\text { drying }\end{array}$} & $\begin{array}{l}\text { Strawberry } \\
\text { Fragaria } x \text { ananassa; } \\
\text { Banana } \\
\text { Musa acuminata }\end{array}$ & $\begin{array}{l}\text { A smoothie containing } 40 \% \text { strawberry and } 60 \% \text { banana stood out for } \\
\text { its taste, odor, viscosity, flavor, general acceptance, sweetness intensity, } \\
\text { and fruit flavor, as well as color tone. }\end{array}$ & Guazi et al. (2019) \\
\hline & $\begin{array}{l}\text { Guavira } \\
\text { C. adamantium }\end{array}$ & $\begin{array}{l}\text { Dehydration of guavira pulp obtained by the foam mat drying method } \\
\text { produced a powder with } 98 \mathrm{mg} \text { of vitamin } \mathrm{C} \text { in } 100 \mathrm{~g} \text { of powder even } \\
\text { after } 45 \text { days of storage. }\end{array}$ & Breda et al. (2012) \\
\hline & $\begin{array}{l}\text { Grape } \\
\text { Vitis labrusca }\end{array}$ & $\begin{array}{l}\text { Foam mat dehydration made it possible to obtain grape powder with } \\
\text { retention of phenolic compounds and antioxidant activity. }\end{array}$ & $\begin{array}{l}\text { Carvalho Tavares et al. } \\
(2019)\end{array}$ \\
\hline & Papaya Carica papaya & $\begin{array}{l}\text { At the end, papaya powder resulted in } 126 \mathrm{mg} \text { of ascorbic acid per } 100 \\
\mathrm{~g} \text { of sample. }\end{array}$ & Pandith (2018) \\
\hline & $\begin{array}{l}\text { Blueberry Vaccinium } \\
\text { myrtillus }\end{array}$ & $\begin{array}{l}\text { The foam mat technique produced highly stable blueberry foam } \\
\text { solutions with a } 74 \% \text { process yield and } 2.6 \% \text { moisture. }\end{array}$ & Darniadi et al. (2018) \\
\hline \multirow[t]{3}{*}{ Freeze drying } & $\begin{array}{l}\text { Marolo } \\
\text { Annona crassiflora }\end{array}$ & $\begin{array}{l}\text { The best drying performance was for the lyophilized marolo compared } \\
\text { to the methods spray and fluidized bed. }\end{array}$ & Pellicer et al. (2019) \\
\hline & $\begin{array}{l}\text { Bocaiuva Acrocomia } \\
\text { aculeata }\end{array}$ & $\begin{array}{l}\text { After the analyses, the results showed that the pulp and powder of the } \\
\text { grugru palm are products with a high content of soluble solids and a } \\
\text { low acidity, highlighting the high levels of } \beta \text {-carotene and vitamin A. }\end{array}$ & Oliveira et al. (2014) \\
\hline & $\begin{array}{l}\text { Araçá } \\
\text { Psidium guineense; } \\
\text { Baru } \\
\text { Dipteryx alata; } \\
\text { Mangaba } \\
\text { Hancornia speciosa }\end{array}$ & $\begin{array}{l}\text { The pulp powder of the fruits studied showed an antioxidant potential } \\
\text { and probably its bioactive characteristics may reduce the damage } \\
\text { caused by oxidative stress. }\end{array}$ & Araujo et al. (2016) \\
\hline \multirow[t]{6}{*}{ Spray drying } & $\begin{array}{l}\text { Cashew } \\
\text { Anacardium occidentale }\end{array}$ & $\begin{array}{l}\text { At the end of the process, the authors concluded that spray drying, } \\
\text { in addition to dehydrating, promotes the formation of cashew juice } \\
\text { microcapsules when encapsulating agents are incorporated, enabling } \\
\text { the retention of sensitive compounds such as vitamin C, present in the } \\
\text { food matrix. }\end{array}$ & Bastos et al. (2012) \\
\hline & $\begin{array}{l}\text { Orange } \\
\text { Citrus sinensis }\end{array}$ & $\begin{array}{l}\text { The technique allowed the production of a powdered orange essential } \\
\text { oil, forming microparticles with up to } 90 \% \text { of oil. In addition, the } \\
\text { analytical method has other advantages, such as operational simplicity. }\end{array}$ & Aguiar et al. (2020) \\
\hline & $\begin{array}{l}\text { Guavira } \\
\text { C. damantium }\end{array}$ & $\begin{array}{l}\text { There was a significant reduction in leukocyte migration to different } \\
\text { doses of microencapsulated guava pulp. }\end{array}$ & Viscardi et al. (2017) \\
\hline & $\begin{array}{l}\text { Hibiscus } \\
\text { Hibiscus sabdariffa }\end{array}$ & $\begin{array}{l}\text { There were also retention of anthocyanins and antioxidant compounds, } \\
\text { low water activity, high solubility, and predominance of a dark red } \\
\text { color, which makes it possible to be applied in various food products. }\end{array}$ & Martins et al. (2020) \\
\hline & $\begin{array}{l}\text { Avocado } \\
\text { Persea Americana }\end{array}$ & $\begin{array}{l}\text { Spray drying allowed obtaining an avocado powder with a high level of } \\
\text { nutritional value, protein retention, phenolic compounds, and ascorbic } \\
\text { acid. It also kept the colorimetric and sensory characteristics of the } \\
\text { avocado pulp in natura. }\end{array}$ & Dantas et al. (2018) \\
\hline & $\begin{array}{l}\text { Pomegranate } \\
\text { Punica granatum }\end{array}$ & $\begin{array}{l}\text { At the end of the process, authors obtained powdered pomegranate } \\
\text { juice and concluded that the temperature of the input air may affect } \\
\text { powder density, while the level of maltodextrin may affect the } \\
\text { anthocyanin content of the powder. }\end{array}$ & Jafari et al. (2017) \\
\hline \multirow[t]{2}{*}{ Spouted bed drying } & $\begin{array}{l}\text { Acerola } \\
\text { Malpighia emarginata }\end{array}$ & $\begin{array}{l}\text { The final powder product showed satisfactory nutritional and bioactive } \\
\text { attributes, with } 72.9 \% \text { ascorbic acid retention. }\end{array}$ & Dantas et al. (2019) \\
\hline & $\begin{array}{l}\text { Camu-camu Myrciaria } \\
\text { dubia }\end{array}$ & $\begin{array}{l}\text { Despite the losses caused by drying, camu-camu powders are still } \\
\text { excellent sources of bioactive compounds with a great potential for use } \\
\text { as new bioactive ingredients. }\end{array}$ & Fujita et al. (2013) \\
\hline
\end{tabular}


the food by the thermal vaporization mechanism. It is carried out by means of heat produced artificially under controlled conditions of temperature, moisture, and airflow. The tray dryer is the most used equipment in this type of operation. Drying is carried out in batches of product. Air heating is generally created by means of electrical resistance, but other energy sources can be used, such as burning LPG gas, using steam in heat exchangers, and solar energy depending on the economic and environmental aspects (Tatar Turan et al., 2016).

The combination of osmotic dehydration with convective dehydration in trays resulted in a $17 \%$ higher acceptability, further reducing the dehydration time by $42 \%$ compared to conventionally dried pears of the Willians variety (Pyrus communis). Thus, the combination of techniques is effective to obtain pears with a low water activity and better general characteristics (Costa Ribeiro et al., 2016).

Osmotic dehydration together with artificial drying in an oven was also used for the production of dehydrated cagaita (Eugenia dysenterica). Cagaita is a typical fruit of the Brazilian Cerrado appreciated for its acid flavor and richness in vitamin C, fibers, and carotenoids. Sucrose was used as an osmotic agent at three concentrations/dehydration temperatures $\left(45^{\circ} \mathrm{Brix} / 50^{\circ} \mathrm{C}\right.$, $45^{\circ} \mathrm{Brix} / 70^{\circ} \mathrm{C}$, and $65^{\circ} \mathrm{Brix} / 50^{\circ} \mathrm{C}$ ). Dehydrated cagaitas were sent for sensory analysis, and the different treatments showed a good acceptance, constituting a valid option regarding the increase in useful life and consequently the improvement in the added value of the fruit (Silva et al., 2015).

The marolo (Annona crassiflora Mart.), also known as araticum, is also a typical South American fruit (Figure 1). Its pulp is rich in vitamin $\mathrm{C}$, magnesium, and carotenoids, and it is consumed in natura or as sweets, jellies, juices, and liqueurs (Vilar et al., 2008). In this context, Botrel et al. (2016) dehydrated the marolo pulp using the thin layer convection drying method at different drying temperatures $\left(70{ }^{\circ} \mathrm{C}, 80^{\circ} \mathrm{C}\right.$, and $\left.90^{\circ} \mathrm{C}\right)$. In this study, convection dehydration combined with the thin layer technique was an effective alternative for obtaining powdered marolo, increasing the pulp's useful life and enabling the development of innovative products in the food industry.

Certain nutritional properties of foods, especially vitamins, can be affected in processes with heat treatment with drying by dehydration. The impacts on the quality of the dehydrated product, with deterioration of flavor and color, are decreases in water absorption capacity and displacement of solutes from the internal part of the material to the surface due to the long drying periods and the high temperatures at which food needs to be subjected for an effective dehydration (Tatar Turan et al., 2016; Engel et al., 2016).

\subsection{Dehydration by lyophilization}

The main phenomenon involved in lyophilization is sublimation, where water passes directly from the solid state (ice) to the gaseous state (water vapor) without going through the liquid state (Figure 2). The material to be dehydrated is first frozen and then subjected to high vacuum (by conduction, radiation, or both) so that the frozen liquid sublimates, remaining only the dry components (Kawasaki et al., 2019).

The water vapor concentration gradient between the drying front and the condenser is the driving force for removing water during lyophilization. The entire process is carried out at low temperature and pressure, so it is suitable for drying thermolabile compounds. During the lyophilization process, moisture from the fruit is removed at low temperatures, favoring the preservation of nutrients and bioactive substances, and maintaining the flavor and the peculiar characteristics of the pulp, preventing, or delaying deterioration reactions and prolonging its shelf life (Kawasaki et al., 2019).

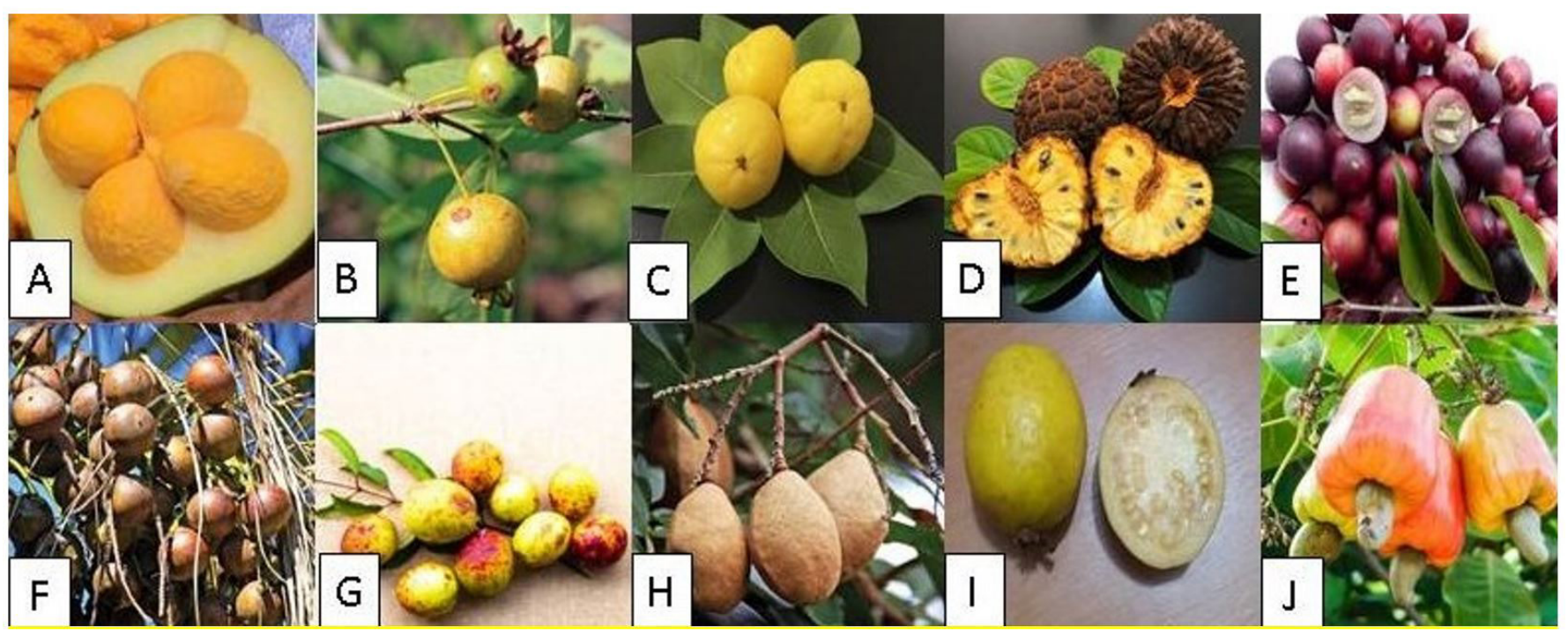

Figure 1. Main native fruits of South America, addressed in this study. (A) Pequi (Caryocar brasiliense); (B) Guavira (Campomanesia adamantium); (C) Cagaita (Eugenia dysenterica); (D) Marolo (Annona crassiflora); (E) Camu-camu (Myrciaria dubia); (F) Bocaiuva (Acrocomia aculeata); (G) Mangaba (Hancornia speciosa); (H) Baru (Dipteryx alata); (I) Araçá (Psidium guineense); (J) Caju (Anacardium occidentale). Source: Giacon (2021). 
Lyophilization has already been used in the dehydration of fruits popularly used in traditional medicine by riverside, indigenous, and Pantanal populations. The araçá (Psidium guineense Swartz), baru (Dipteryx alata Vogel), guavira (Campomanesia pubescens DC. O. Berg), mangaba (Hancornia speciosa Gomez) and (Annona crassiflora Mart.) were characterized as for antioxidant activity after dehydration by lyophilization. The researchers found that even after lyophilization, the pulps of the fruits showed an antioxidant potential and probably these bioactive characteristics of the fruits may reduce the damage caused by oxidative stress (Araujo et al., 2016).

Lyophilization of fruit juices and pulps with a high content of low molecular weight sugar (fructose and glucose) may result in sticky powders at room temperature. This is due to the amorphous state in which part of the sugar is found, favoring stickiness, agglomeration, and compaction. In addition, the porous structure of lyophilized foods is fragile and brittle, presenting empty spaces that favor access to oxygen, which may cause degradation of vitamin $\mathrm{C}$ by oxidation. Other bottlenecks that need attention in freeze drying are the high costs of equipment and high consumption of electricity during the process (Sagar \& Kumar, 2010).

\subsection{Spray drying}

The spray drying method is characterized by the transformation of a liquid into a dry product in the form of a powder (Figure 3 ). The liquid is atomized in a centrifugal or high-pressure system, where the atomized droplets come into contact with a flow
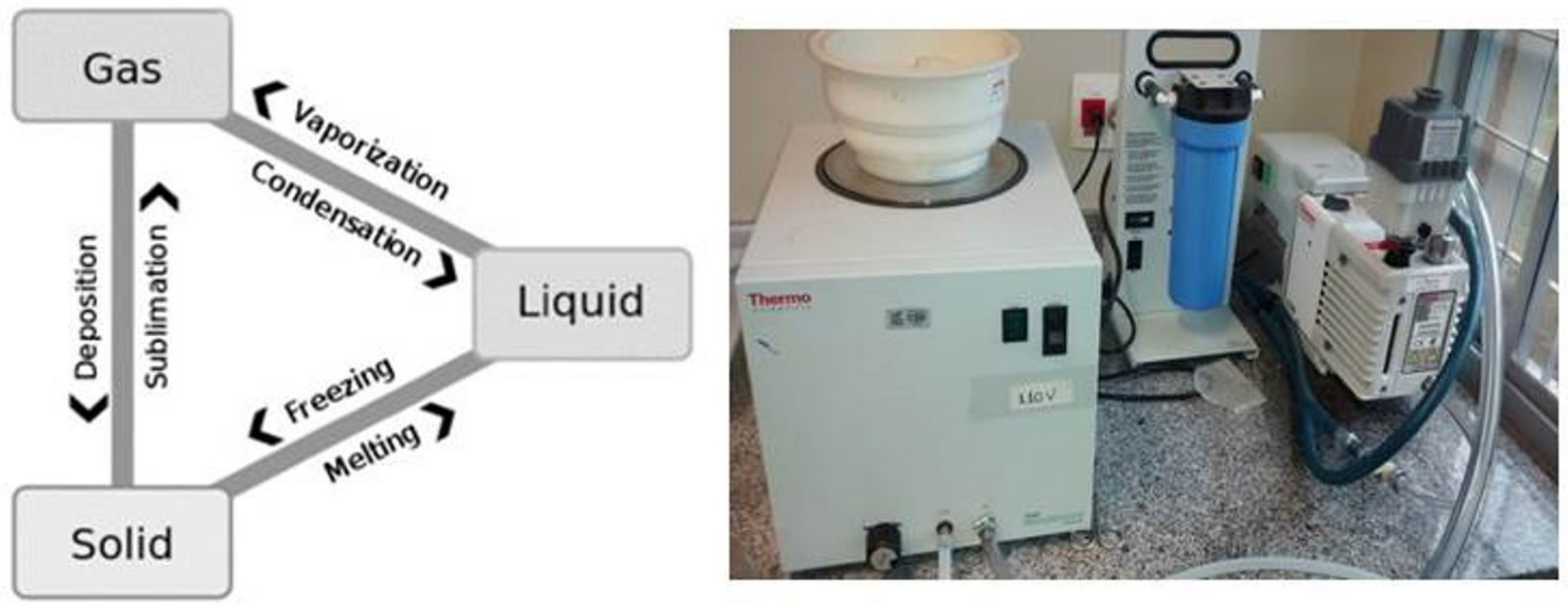

Figure 2. Lyophilizer, ThermoFisher, Thermo scientific. Source: Thermo scientific (2021).
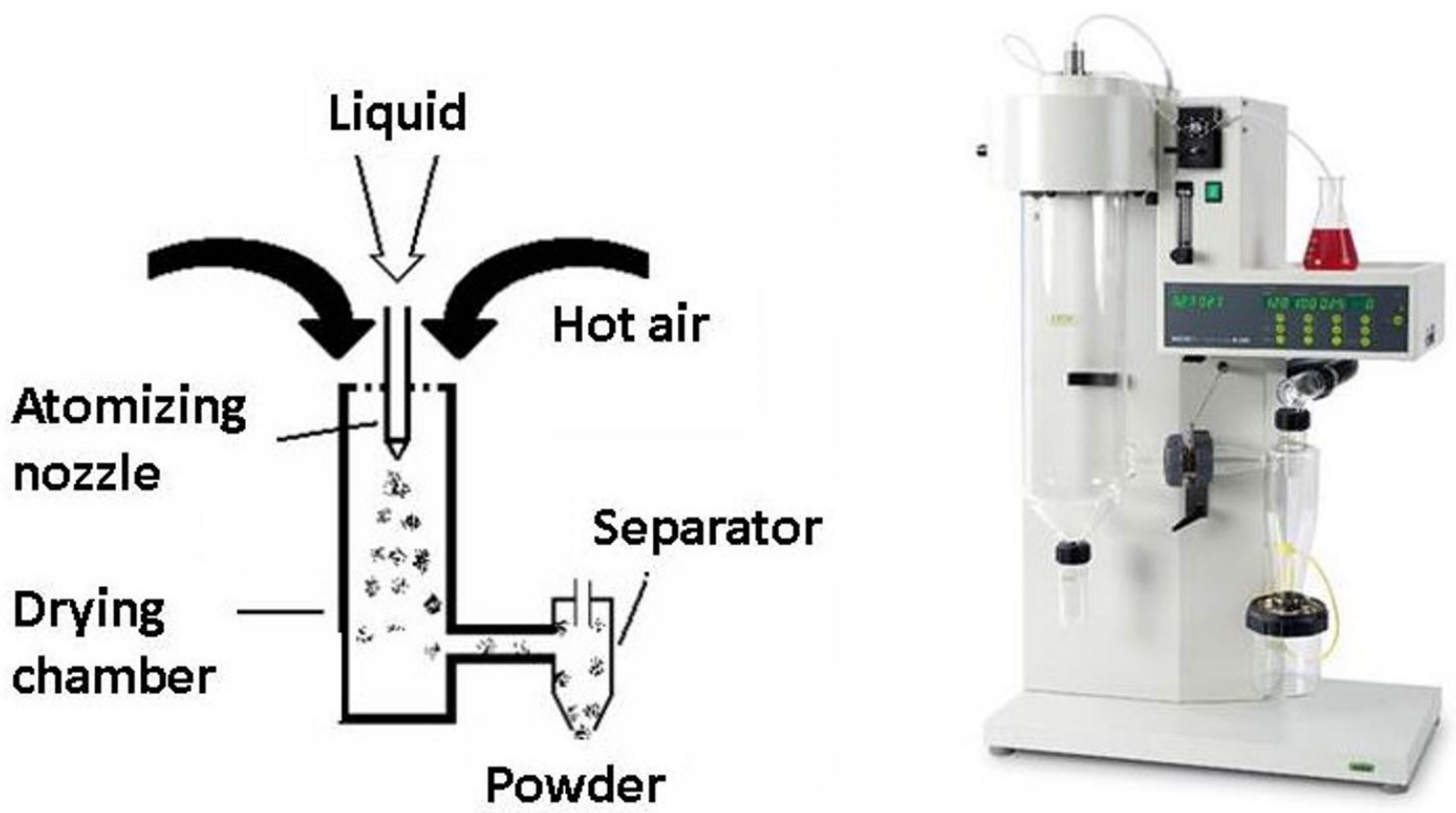

Figure 3. Dehydration scheme by spray drying and mini spray drying apparatus, Buchi, B-290. Source: Dryer Büchi (2021). 
of hot air. Thus, there is a fast evaporation, which allows the temperature of the final product to be kept low and the drying of heat-sensitive products without excessively affecting their quality due to the short process time (I Ré, 1998). The atomization process favors a high-quality juice or powdered pulp, since the heat treatment is quick and simple, as Figure 4 shows, avoiding product deterioration (Assadpour \& Jafari, 2019).

The differential of this process is the short time the pulp remains in the dryer, which favors the conservation of thermosensitive substances. Another differential of this process is the large-scale production capacity with low energy cost (I Ré, 1998). Spray drying was also applied to dehydrate cashew juice (Anacardium occidentale L.), and, at the end of the process, the authors concluded that spray drying, in addition to dehydrating, promotes the formation of cashew juice microcapsules when encapsulating agents are incorporated, enabling the retention of sensitive compounds such as vitamin C, present in the food matrix (Bastos et al., 2012).

Spray drying was also applied in the production of powdered pequi oil (Caryocar brasiliense Camb.) (Pinto et al., 2018). This technique was also used in different studies using different carrier agents for the development of microencapsulated pequi oil, with a better protection as for its antioxidant activity compared to bulk oil (Oliveira et al., 2014). The anti-inflammatory activity of guavira microcapsules (Campomanesia adamantium) was tested in an animal model. There was a significant reduction in leukocyte migration according to the different doses of microencapsulated guavira pulp evaluated compared with the control group. The spray drying technique is an alternative for microencapsulation of natural products, ensuring the bioavailability and preservation of bioactive components in the guavira pulp (Viscardi et al., 2017).

The spray drying method was applied to dehydrate hibiscus (Hibiscus sabdariffa) under different drying parameters, obtaining, at the end of the process, an extract of $H$. sabdariffa with retention of anthocyanins and antioxidant compounds. In addition, the powder extract showed low water activity, high solubility, and predominance of a dark red color, which allows its application in several food products (Martins et al., 2020).

The high sugar content in fruit juice may result in products with a high hygroscopicity, decreasing the process yield. Therefore, it is essential to use carrier agents with a high molecular weight before atomization to facilitate the drying process and the transport and storage operations. Maltodextrin is the carrier agent commonly used in spray drying due to its low hygroscopicity, high solubility in cold water, and low cost (Sagar \& Kumar, 2010).

\subsection{Microencapsulation of bioactive vegetable ingredients as natural antioxidants}

Some dehydration techniques, in addition to drying the product, can provide microencapsulation of bioactive substances.

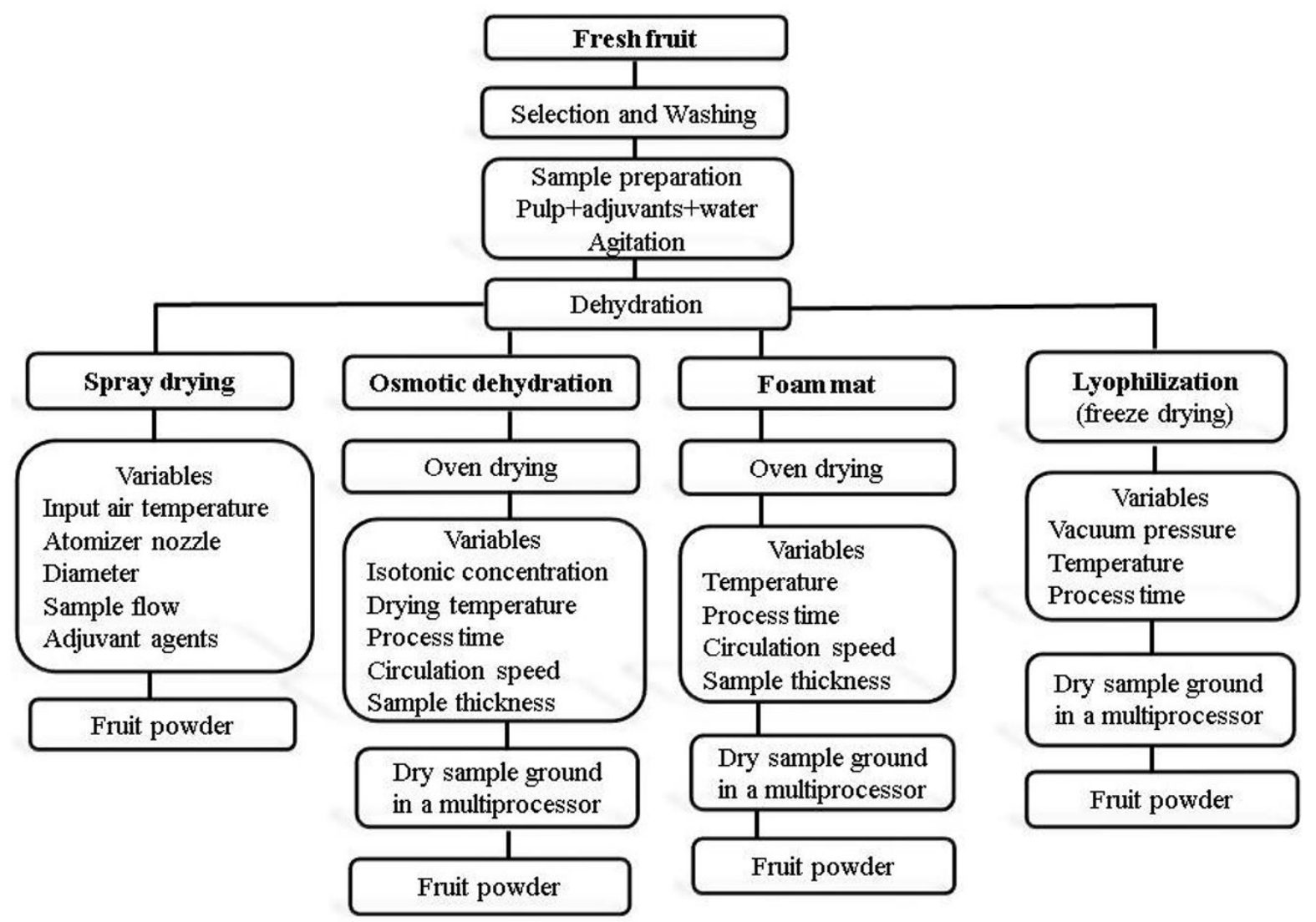

Figure 4. Schematic representation of the main techniques used for the dehydration of fruits. 
Microencapsulation consists of involving small particles (through an encapsulating agent) of liquid or gaseous materials and forming miniature capsules, called active material, which can release its contents under controlled conditions or under specific conditions, helping to protect the bioactive agents contained in the encapsulated pulp against degradation factors such as light, oxygen, heat, $\mathrm{pH}$, water, and other deteriorating factors (Pathakoti et al., 2017; Ray et al., 2016). It aims to improve the characteristics of bioactive ingredients, that is, functionality, solubility, bioavailability, and nutritional value.

The techniques frequently studied and used to encapsulate bioactive from food are lyophilization, spray drying, fluidized bed coating, foam mat, and systems based on supercritical fluids (Can Karaca et al., 2020; García-Ruiz et al., 2017). Among

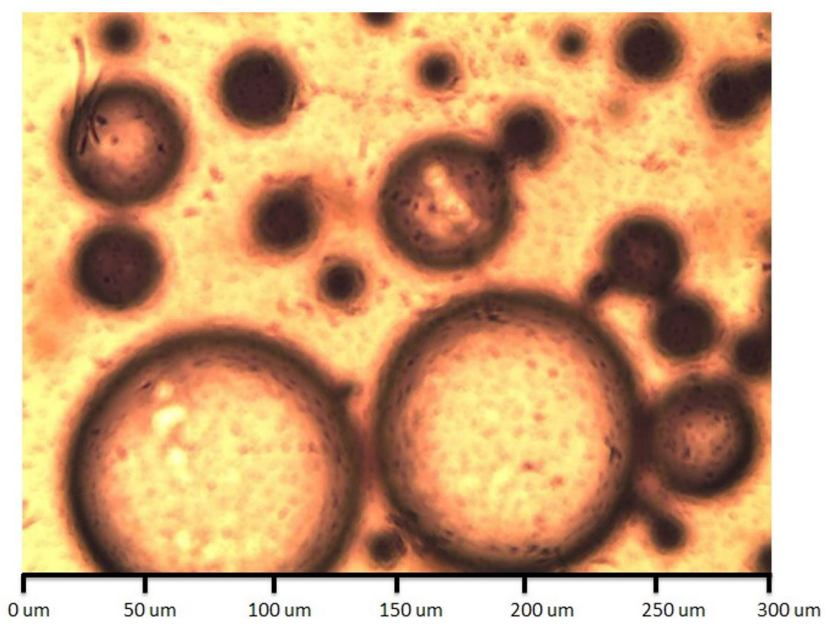

Figure 5. Micrographs of Campomanesia adamantium pulp samples produced by lyophilization with a mixture of $24 \%$ maltodextrin. $250 \mathrm{x}$ magnification. Source: Oliveira et al. (2015).

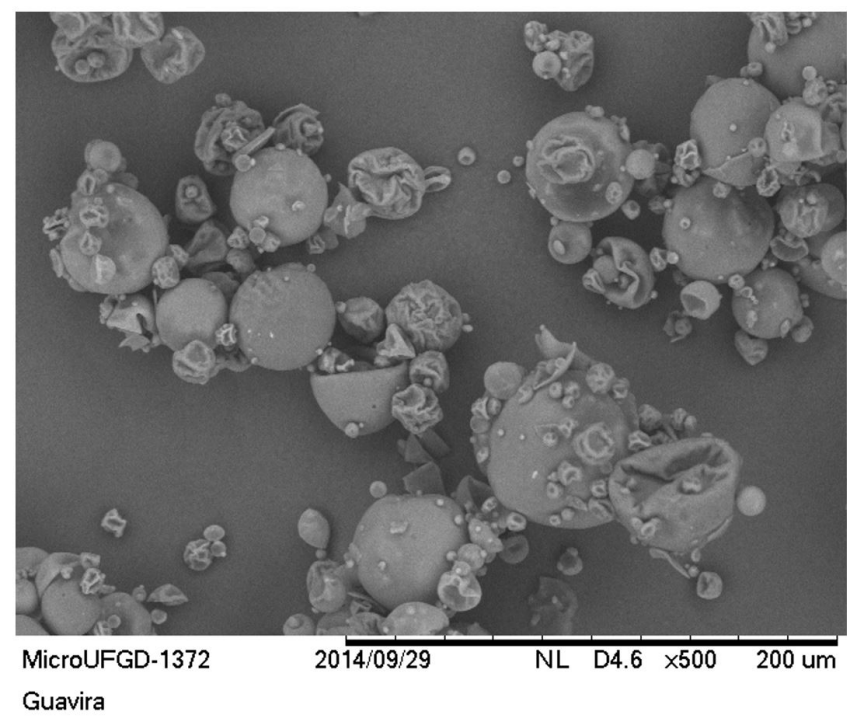

Figure 6. Micrographs of Campomanesia adamantium pulp samples produced by atomization at $180{ }^{\circ} \mathrm{C}$ with a mixture of $8 \%$ maltodextrin, $8 \%$ gum arabic, and $8 \%$ chitosan. Images with (A) $500 x$ and (B) $1,500 x$ magnification. Source: Oliveira et al. (2015). these techniques, the lyophilization is highlighted as one of the best methods for obtaining microcapsules (Figure 5) of the biological materials with high quality, being recommended for thermosensitive bioactive compounds such as vitamins or highadded value products. During the process, the product's water is removed by sublimation at low temperatures, minimizing thermal degradation reactions, favoring the preservation of nutrients, flavors, aromas and bioactive components present in the product. In freeze-dried food, most spoilage and microbiological reactions are inhibited, prolonging its shelf life (Rezvankhah et al., 2019).

Another highlight is spray drying, a widespread method whose advantages include good retention of nutrients and bioactive substances, large-scale production, and lower costs in relation to freeze drying (Lipan et al., 2020; Fortunati et al., 2019).

The most used encapsulating agents in the food industry are gum arabic, maltodextrin, and chitosan, which may be applied separately or incorporated into mixtures previously created by previous optimization studies, according to the microcapsules shown in Figure 6. These microencapsulating agents, in conjunction with the techniques already presented, can provide the formation of capsules with different sizes and shapes, that is, macroparticles $(\geq 5,000 \mu \mathrm{m})$, microparticles (0.2 to $5,000 \mu \mathrm{m})$, and nanoparticles $(\leq 0.2 \mu \mathrm{m})$.

\section{Conclusion}

The creation and/or development of products using fruits native to South America by means of efficient dehydration technologies, with a long useful life and good preservation of bioactive compounds, allows the valorization, distribution, and commercialization of food plants, especially in the off-season period, as foods that have added value, thus strengthening the economy of the rural population, and stimulating the preservation of biodiversity, as well as the culture of native peoples.

In this work, five techniques for dehydrating products made with native fruits are presented and successfully used/ tested in the processing and conservation of Cerrado and Pantanal fruits. However, the techniques with better results in the retention of bioactive compounds and the maintenance of the organoleptic characteristics of the fruits are different from those that present better performance in energy efficiency and large-scale production.

Future research should be focused on the development of technologies that combine more than one conservation method. Then, these news dimensions should be came up in drying technology to improve product quality and durability and reduce energy utilization and operational cost; and thus, other procedures may be available on the dehydration process of native fruits.

\section{Funding}

This study was financed in part by the Coordenação de Aperfeiçoamento de Pessoal de Nível Superior, Brazil (CAPES) Finance Code 001. 


\section{Acknowledgements}

We thank the Graduate Program in the Health and Development in the Central-West Region of Brazil, Federal University of Mato Grosso do Sul-UFMS and the Coordenação de Aperfeiçoamento de Pessoal de Nível Superior. We also thank Brazil (CAPES) for support.

\section{References}

Abbasi, E., \& Azizpour, M. (2016). Evaluation of physicochemical properties of foam mat dried sour cherry powder. LebensmittelWissenschaft + Technologie, 68, 105-110. http://dx.doi.org/10.1016/j. lwt.2015.12.004.

Abreu, R. C., Hoffmann, W. A., Vasconcelos, H. L., Pilon, N. A., Rossatto, D. R., \& Durigan, G. (2017). The biodiversity cost of carbon sequestration in tropical savanna. Science Advances, 3(8), e1701284. http://dx.doi.org/10.1126/sciadv.1701284. PMid:28875172.

Aguiar, M. C. S., das Graças Fernandes da Silva, M. F., Fernandes, J. B., \& Forim, M. R. (2020). Evaluation of the microencapsulation of orange essential oil in biopolymers by using a spray-drying process. Scientific Reports, 10(1), 11799. http://dx.doi.org/10.1038/s41598020-68823-4. PMid:32678230.

Ahmed, I., Qazi, I. M., \& Jamal, S. (2016). Developments in osmotic dehydration technique for the preservation of fruits and vegetables. Innovative Food Science \& Emerging Technologies, 34, 29-43. http:// dx.doi.org/10.1016/j.ifset.2016.01.003.

Amami, E., Khezami, W., Mezrigui, S., Badwaik, L. S., Bejar, A. K., Perez, C. T., \& Kechaou, N. (2017). Effect of ultrasound-assisted osmotic dehydration pretreatment on the convective drying of strawberry. Ultrasonics Sonochemistry, 36, 286-300. http://dx.doi.org/10.1016/j. ultsonch.2016.12.007. PMid:28069213.

Amit, S. K., Uddin, M. M., Rahman, R., Islam, S. M. R., \& Khan, M. S. (2017). A review on mechanisms and commercial aspects of food preservation and processing. Agriculture \& Food Security, 6(1), 51. http://dx.doi.org/10.1186/s40066-017-0130-8.

Araujo, L. C. A., Rios, N. L., Boleti, A. P. A., \& dos Santos, E. L. (2016). Profile of antioxidant activity of fruits of the savanna brazilian. Free Radical Biology \& Medicine, 100, S95. http://dx.doi.org/10.1016/j. freeradbiomed.2016.10.237.

Assadpour, E., \& Jafari, S. M. (2019). Advances in spray-drying encapsulation of food bioactive ingredients: From microcapsules to nanocapsules. Annual Review of Food Science and Technology, 10(1), 103-131. http://dx.doi.org/10.1146/annurev-food-032818-121641. PMid:30649963.

Ban, Z., Zhang, J., Li, L., Luo, Z., Wang, Y., Yuan, Q., Zhou, B., \& Liu, H. (2020). Ginger essential oil-based microencapsulation as an efficient delivery system for the improvement of Jujube (Ziziphus jujuba Mill.) fruit quality. Food Chemistry, 306, 125628. http://dx.doi. org/10.1016/j.foodchem.2019.125628. PMid:31629297.

Bastos, D. S., Gonçalves, M. P., Andrade, C. T., Araújo, K. G. L., \& Rocha Leão, M. H. M. (2012). Microencapsulation of cashew apple (Anacardium occidentale, L.) juice using a new chitosan-commercial bovine whey protein isolate system in spray drying. Food and Bioproducts Processing, 90(4), 683-692. http://dx.doi.org/10.1016/j. fbp.2012.04.005.

Benton, D., \& Young, H. A. (2019). Role of fruit juice in achieving the 5-a-day recommendation for fruit and vegetable intake. Nutrition Reviews, 77(11), 829-843. http://dx.doi.org/10.1093/nutrit/nuz031. PMid:31504822.
Boeri, P., Piñuel, L., Dalzotto, D., \& Sharry, S. (2020). Native biodiversity: a strategic resource to accelerate bioeconomy development in latin america and the caribbean. In P. Chong, D. Newman \& D. Steinmacher (Eds.), Agricultural, forestry and bioindustry biotechnology and biodiscovery (pp. 163-174). Cham: Springer. http://dx.doi. org/10.1007/978-3-030-51358-0_10.

Botrel, D. A., Rodrigues, I. C. B., Souza, H. J. B., \& Fernandes, R. V. B. (2016). Application of inulin in thin-layer drying process of araticum (Annona crassiflora) pulp. Lebensmittel-Wissenschaft + Technologie, 69, 32-39. http://dx.doi.org/10.1016/j.lwt.2016.01.018.

Bozkir, H., Rayman Ergün, A., Serdar, E., Metin, G., \& Baysal, T. (2019). Influence of ultrasound and osmotic dehydration pretreatments on drying and quality properties of persimmon fruit. Ultrasonics Sonochemistry, 54, 135-141. http://dx.doi.org/10.1016/j. ultsonch.2019.02.006. PMid:30765216.

Breda, C. A., Sanjinez-Argandoña, E. J., \& Correia, C. A. (2012). Shelf life of powdered Campomanesia adamantium pulp in controlled environments. Food Chemistry, 135(4), 2960-2964. http://dx.doi. org/10.1016/j.foodchem.2012.07.029. PMid:22980897.

Can Karaca, A., Baskaya, H., Guzel, O., \& Ak, M. M. (2020). Characterization of some physicochemical properties of spray-dried and freeze-dried sour cherry powders. Journal of Food Processing and Preservation, $\bullet . \bullet, 14975$.

Carvalho Tavares, I. M., de Castilhos, M. B. M., Mauro, M. A., Ramos, A. M., de Souza, R. T., Gómez-Alonso, S., \& Lago-Vanzela, E. S. (2019). BRS Violeta (BRS Rúbea $\times$ IAC 1398-21) grape juice powder produced by foam mat drying. Part I: Effect of drying temperature on phenolic compounds and antioxidant activity. Food Chemistry, 298, 124971. http://dx.doi.org/10.1016/j.foodchem.2019.124971. PMid:31260997.

Costa Ribeiro, A. S., Aguiar-Oliveira, E., \& Maldonado, R. R. (2016). Optimization of osmotic dehydration of pear followed by conventional drying and their sensory quality. Lebensmittel-Wissenschaft + Technologie, 72, 407-415. http://dx.doi.org/10.1016/j.lwt.2016.04.062.

Dantas, S. C. M., Pontes Júnior, S. M., Medeiros, F. G. M., Santos Júnior, L. C., Alsina, O. L. S., \& Medeiros, M. F. D. (2019). Spouted-bed drying of acerola pulp (Malpighia emarginata DC): effects of adding milk and milk protein on process performance and characterization of dried fruit powders. Journal of Food Process Engineering, 42(6), e13205. http://dx.doi.org/10.1111/jfpe.13205.

Dantas, D., Pasquali, M. A., Cavalcanti-Mata, M., Duarte, M. E., \& Lisboa, H. M. (2018). Influence of spray drying conditions on the properties of avocado powder drink. Food chemistry, 266, 284-291. https://doi.org/10.1016/j.foodchem.2018.06.016.

Darniadi, S., Ho, P., \& Murray, B. S. (2018). Comparison of blueberry powder produced via foam-mat freeze-drying versus spray-drying: evaluation of foam and powder properties. Journal of the Science of Food and Agriculture, 98(5), 2002-2010. http://dx.doi.org/10.1002/ jsfa.8685. PMid:28940205.

Dryer Büchi, S. (2021). Buchi. Retrieved from https://www.buchi.com/ pt/produtos/instrumentos/mini-spray-dryer-b-290.

Engel, B., de Monte Baccar, N., Marquardt, L., de Oliveira, M. S. R. \& Rohlfes, A. L. B. (2016). Tecnologias de atomização e desidratação: alternativas para a produção de farinhas a partir de vegetais. Revista Jovens Pesquisadores, 6(1), 31-44. http://dx.doi.org/10.17058/rjp. v6i1.7345.

Fortunati, E., Mazzaglia, A., \& Balestra, G. M. (2019). Sustainable control strategies for plant protection and food packaging sectors by natural substances and novel nanotechnological approaches. Journal of the Science of Food and Agriculture, 99(3), 986-1000. http://dx.doi.org/10.1002/jsfa.9341. PMid:30191564. 
Fujita, A., Borges, K., Correia, R., Franco, B. D. G. M., \& Genovese, M. I. (2013). Impact of spouted bed drying on bioactive compounds, antimicrobial and antioxidant activities of commercial frozen pulp of camu-camu (Myrciaria dubia Mc. Vaugh). Food Research International, 54(1), 495-500. http://dx.doi.org/10.1016/j.foodres.2013.07.025.

García-Ruiz, A., Girones-Vilaplana, A., León, P., Moreno, D. A., Stinco, C. M., Meléndez-Martínez, A. J., \& Ruales, J. (2017). Banana passion fruit (Passiflora mollissima (Kunth) LH Bailey): Microencapsulation, phytochemical composition and antioxidant capacity. Molecules (Basel, Switzerland), 22(1), 85. http://dx.doi.org/10.3390/molecules22010085. PMid:28106710.

Giacon, G. (2021). Retrieved from https://www.instagram.com/ gustavogiacon.

Guazi, J. S., Lago-Vanzela, E. S., \& Conti-Silva, A. C. (2019). Development of smoothies from dehydrated products of strawberry and banana pulps obtained through foam-mat drying. International Journal of Food Science \& Technology, 54(1), 54-61. http://dx.doi.org/10.1111/ ijfs. 13900 .

Herforth, A., Bai, Y., Venkat, A., Mahrt, K., Ebel, A., \& Masters, W. A. (2020). Cost and affordability of healthy diets across and within countries: Background paper for The State of Food Security and Nutrition in the World 2020 (FAO Agricultural Development Economics Technical Study No. 9 (vol. 9). Rome: FAO.

I Ré, M. (1998). Microencapsulation by spray drying. Drying Technology, 16(6), 1195-1236. http://dx.doi.org/10.1080/07373939808917460.

Jafari, S. M., Ghalenoei, M. G., \& Dehnad, D. (2017). Influence of spray drying on water solubility index, apparent density, and anthocyanin content of pomegranate juice powder. Powder Technology, 311, 5965. http://dx.doi.org/10.1016/j.powtec.2017.01.070.

Kawasaki, H., Shimanouchi, T., \& Kimura, Y. (2019). Recent development of optimization of lyophilization process. Journal of Chemistry, 2019, 9502856. http://dx.doi.org/10.1155/2019/9502856.

Lipan, L., Rusu, B., Sendra, E., Hernández, F., Vázquez-Araújo, L., Vodnar, D. C., \& Carbonell-Barrachina, Á. A. (2020). Spray drying and storage of probiotic-enriched almond milk: probiotic survival and physicochemical properties. Journal of the Science of Food and Agriculture, 100(9), 3697-3708. http://dx.doi.org/10.1002/jsfa.10409. PMid:32248520.

Martins, D. R. D. S., Sanjinez-Argandoña, E. J., Ortega, N. D. F., Garcia, V. A. D. S., Oliveira, V. S., \& Cardoso, C. A. L. (2020). Production and characterization of Hibiscus sabdariffa by spray dryer using different sprinkler nozzles and carrier agents. Journal of Food Processing and Preservation, 44(7), e14493. https://doi.org/10.1111/jfpp.14493.

Nowacka, M., Tylewicz, U., Romani, S., Dalla Rosa, M., \& WitrowaRajchert, D. (2017). Influence of ultrasound-assisted osmotic dehydration on the main quality parameters of kiwi fruit. Innovative Food Science \& Emerging Technologies, 41, 71-78. http://dx.doi. org/10.1016/j.ifset.2017.02.002.

Oliveira, D. M., Clemente, E., \& da Costa, J. M. C. (2014). Bioactive compounds and physicochemical parameters of grugru palm (Acrocomia aculeata) from Brazil: pulp and powder. Food Science and Technology Research, 20(1), 7-12. http://dx.doi.org/10.3136/fstr.20.7.

Oliveira, S. V., Sanjinez, A. E. J., Oshiro, M. A., Carnevali, T. O., \& Honorato, C. A. (2015). Desidratação da polpa de Campomanesia adamantium Cambess O. Berg por liofilização. Interbio, 9, 22-27.

Ozkan, G., Franco, P., De Marco, I., Xiao, J., \& Capanoglu, E. (2019). A review of microencapsulation methods for food antioxidants: Principles, advantages, drawbacks and applications. Food Chemistry, 272, 494-506. http://dx.doi.org/10.1016/j.foodchem.2018.07.205. PMid:30309574.
Pandith, J. A. (2018). Induction heating assisted foam mat drying of papaya pulp: drying kinetics, drying modeling, and effects on quality attributes. Agricultural Engineering International: CIGR Journal, 20(2), 206-215.

Pathakoti, K., Manubolu, M., \& Hwang, H. M. (2017). Nanostructures: current uses and future applications in food science. Journal of Food and Drug Analysis, 25(2), 245-253. PMid:28911665.

Pellicer, J. A., Fortea, M. I., Trabal, J., Rodríguez-López, M. I., Gabaldón, J. A., \& Núñez-Delicado, E. (2019). Stability of microencapsulated strawberry flavour by spray drying, freeze drying and fluid bed. Powder Technology, 347, 179-185. http://dx.doi.org/10.1016/j. powtec.2019.03.010.

Pinto, M. R. M. R., Paula, D. A., Alves, A. I., Rodrigues, M. Z., Vieira, É. N. R., Fontes, E. A. F., \& Ramos, A. M. (2018). Encapsulation of carotenoid extracts from pequi (Caryocar brasiliense Camb.) by emulsification (O/W) and foam-mat drying. Powder Technology, 339, 939-946. http://dx.doi.org/10.1016/j.powtec.2018.08.076.

Ray, S., Raychaudhuri, U., Chakraborty, R., Ray, S., Raychaudhuri, U., \& Chakraborty, R. (2016). An overview of encapsulation of active compounds used in food products by drying technology. Food Bioscience, 13, 76-83. http://dx.doi.org/10.1016/j.fbio.2015.12.009.

Rezvankhah, A., Emam-Djomeh, Z., \& Askari, G. (2019). Encapsulation and delivery of bioactive compounds using spray and freeze-drying techniques: A review. Drying Technology, 38(1-2), 235-258. http:// dx.doi.org/10.1080/07373937.2019.1653906.

Rodríguez, Ó., Eim, V., Rosselló, C., Femenia, A., Cárcel, J. A., \& Simal, S. (2018). Application of power ultrasound on the convective drying of fruits and vegetables: effects on quality. Journal of the Science of Food and Agriculture, 98(5), 1660-1673. http://dx.doi.org/10.1002/ jsfa.8673. PMid:28906555.

Sagar, V. R., \& Kumar, P. S. (2010). Recent advances in drying and dehydration of fruits and vegetables: a review. Journal of Food Science and Technology, 47(1), 15-26. http://dx.doi.org/10.1007/ s13197-010-0010-8. PMid:23572596.

Sanchez, B. A. O., Celestino, S. M. C., de Abreu Gloria, M. B., Celestino, I. C., Lozada, M. I. O., Araújo Júnior, S. D., \& de Oliveira, L. D. L. (2020). Pasteurization of passion fruit Passiflora setacea pulp to optimize bioactive compounds retention. Food Chemistry, 6, 100084. PMid:32373788.

Sasson, A., \& Malpica, C. (2018). Bioeconomics in Latin America. New Biotechnology, 40(Pt A), 40-45. http://dx.doi.org/10.1016/j. nbt.2017.07.007. PMid:28716653.

Scoditti, E., Massaro, M., Garbarino, S., \& Toraldo, D. M. (2019). Role of diet in chronic obstructive pulmonary disease prevention and treatment. Nutrients, 11(6), 1357. http://dx.doi.org/10.3390/ nu11061357. PMid:31208151.

Silva, C. D. M., Pires, C. R. F., Lima, J. P., Pereira, A. S., \& Silva, C. A. (2015). Osmotic dehydration to obtain cagaita raisins. Journal of Bioenergy and Food Science, 2(4), 226-233. http://dx.doi.org/10.18067/ jbfs.v2i4.82.

Sun, Y., Zhang, Y., Xu, W., \& Zheng, X. (2020). Analysis of the anthocyanin degradation in blue honeysuckle berry under microwave assisted foam-mat drying. Foods, 9(4), 397. http://dx.doi.org/10.3390/ foods9040397. PMid:32244338.

Tatar Turan, F., Cengiz, A., Sandıkçı, D., Dervisoglu, M., \& Kahyaoglu, T. (2016). Influence of an ultrasonic nozzle in spray-drying and storage on the properties of blueberry powder and microcapsules. Journal of the Science of Food and Agriculture, 96(12), 4062-4076. http://dx.doi.org/10.1002/jsfa.7605. PMid:26749368.

Thermo scientific. (2021). Retrieved from https://www.thermofisher.com. 
van Noordwijk, M., Gitz, V., Minang, P. A., Dewi, S., Leimona, B., Duguma, L., Pingault, N., \& Meybeck, A. (2020). People-centric nature-based land restoration through agroforestry: a typology. Land (Basel), 9(8), 251. http://dx.doi.org/10.3390/land9080251.

Vilar, J. B., Ferreira, F. L., Ferri, P. H., Guillo, L. A., \& Chen Chen, L. (2008). Assessment of the mutagenic, antimutagenic and cytotoxic activities of ethanolic extract of araticum (Annona crassiflora Mart. 1841) by micronucleus test in mice. Brazilian Journal of Biology $=$
Revista Brasileira de Biologia, 68(1), 141-147. http://dx.doi.org/10.1590/ S1519-69842008000100020. PMid:18470389.

Viscardi, D. Z., Oliveira, V. S., Arrigo, J. S., Piccinelli, A. C., Cardoso, C. A. L., Maldonade, I. R., Kassuya, C. A. L., \& Sanjinez-Argandoña, E. J. (2017). Anti-inflammatory, and antinociceptive effects of Campomanesia adamantium microencapsulated pulp. Revista Brasileira de Farmacognosia, 27(2), 220-227. http://dx.doi.org/10.1016/j. bjp.2016.09.007. 